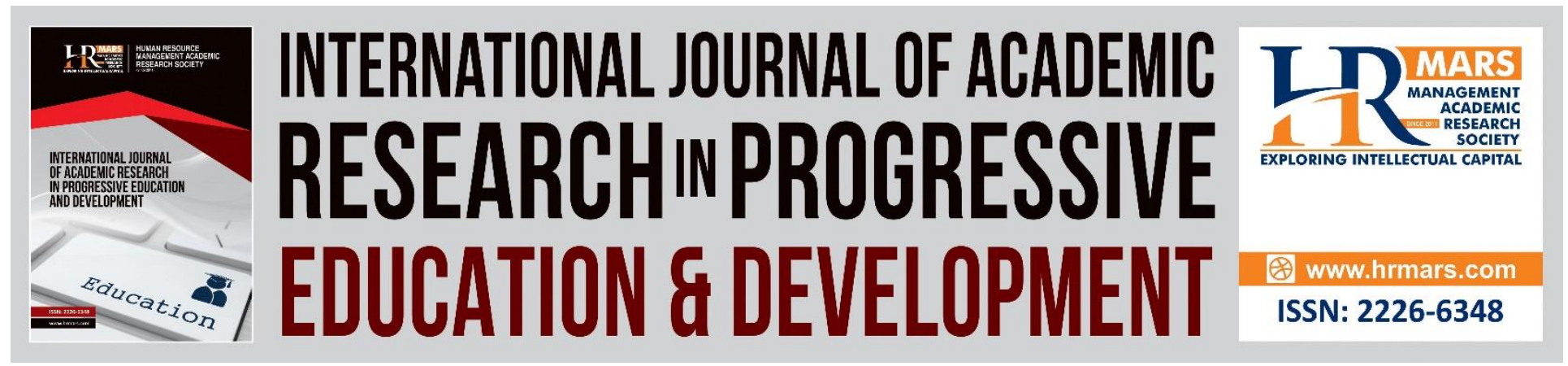

\title{
Impact of Fostering Higher Order Thinking Skills Training Programme on Science Teachers' Knowledge
}

\author{
Nor'ain Mohd Tajudin, Nurulhuda Abd Rahman, Ong Eng Tek, Rosnidar \\ Mansor
}

To Link this Article: http://dx.doi.org/10.6007/IJARPED/v7-i3/4553

DOI: $10.6007 /$ IJARPED/v7-i3/4553

Received: 25 August 2018, Revised: 23 Sept 2018, Accepted: 28 Sept 2018

Published Online: 10 October 2018

In-Text Citation: (Tajudin, Rahman, Tek, \& Mansor, 2018)

To Cite this Article: Tajudin, N. M., Rahman, N. A., Tek, O. E., \& Mansor, R. (2018). Impact of Fostering Higher Order Thinking Skills Training Programme on Science Teachers' Knowledge. International Journal of Academic Research in Progressive Education and Development, 7(3), 453-464.

Copyright: (c) 2018 The Author(s)

Published by Human Resource Management Academic Research Society (www.hrmars.com)

This article is published under the Creative Commons Attribution (CC BY 4.0) license. Anyone may reproduce, distribute, translate and create derivative works of this article (for both commercial and non-commercial purposes), subject to full attribution to the original publication and authors. The full terms of this license may be seen

at: http://creativecommons.org/licences/by/4.0/legalcode

\section{Vol. 7, No. 3, July 2018, Pg. 453 - 464}




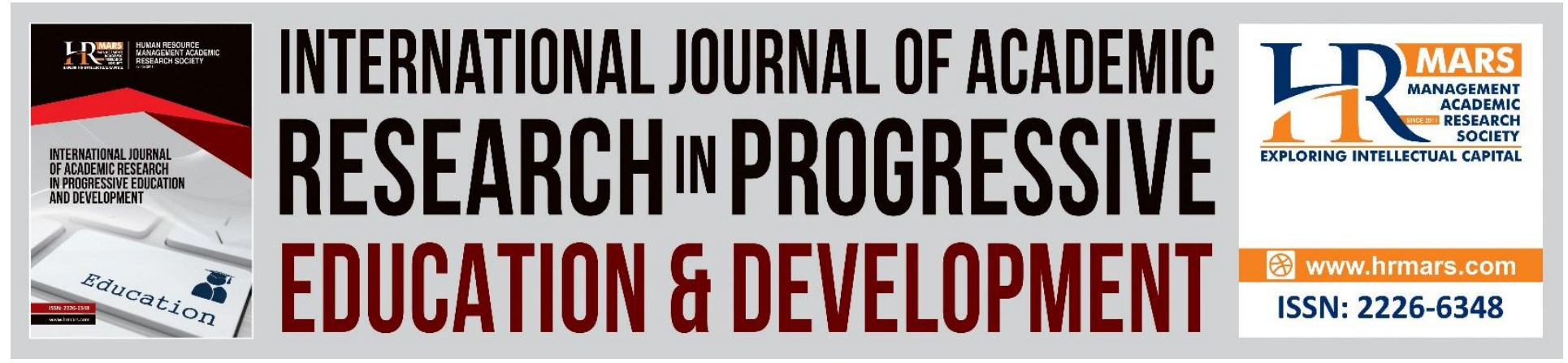

\title{
Impact of Fostering Higher Order Thinking Skills Training Programme on Science Teachers' Knowledge
}

\author{
Nor'ain Mohd Tajudin ${ }^{1}$, Nurulhuda Abd Rahman², Ong Eng Tek ${ }^{3}$, \\ Rosnidar Mansor ${ }^{3}$ \\ ${ }^{1}$ Mathematics Department, Faculty of Science \& Mathematics, \\ ${ }^{2}$ Physics Department, , Faculty of Science \& Mathematics, \\ ${ }^{3}$ Educational Studies Department, Faculty of Human Development, \\ Sultan Idris Education University, Perak, Malaysia \\ Email: a) norain@fsmt.upsi.edu.my, ${ }^{\text {b) }}$ nurulhuda@fsmt.upsi.edu.my, \\ c)ong.engtek@fpm.upsi.edu.my, d)rosnidar@fpm.upsi.edu.my
}

\begin{abstract}
This case-study aimed at examining whether training programme for teaching and learning in fostering Higher Order Thinking Skills (HOTS) enhances science teachers' knowledge. Within a 36-hour, six-month pre-post experimental design, nine science teachers were undergone a series of HOTS training programme. By using an Inventory of Teaching and Learning in Fostering HOTS instrument, and comparing the scores in pre-post tests we have found that the all science teachers in the study showed a significant improvement on their knowledge in teaching and learning to foster HOTS. Our findings suggest that if science teachers purposely and persistently practice higher order thinking strategies there is a good chance for them to be competent in implementing active learning methods with a focus on teaching thinking.
\end{abstract}

Keywords: Higher Order Thinking Skills, Training Programme, Science Teacher, Secondary School

\section{Introduction}

In an attempt to gauge the quality of education using international benchmarking, an unfavourable score by Malaysian students as reflected in the recent TIMSS and PISA recognized a dire need for improved teacher science training namely, pedagogical content knowledge in fostering Higher Order Thinking Skills (HOTS). In 2013, collaboration between Ministry of Education, Teacher Training Division and SEAMEO RECSAM resulted in a national level professional development training for science, mathematics and history teachers which recognizes the transmission of information about HOTS rather than promoting teachers' ability to foster HOTS in their teaching (Ministry of Education, 2013). Improved cascade training model was implemented in stages for this purpose. As of current practice, there is no evident of 


\section{INTERNATIONAL JOURNAL OF ACADEMIC RESEARCH IN PROGRESSIVE EDUCATION AND}

\section{DEVELOPMENT}

Vol. 7, No. 3, July 2018, E-ISSN: 2226-6348 @ 2018 HRMARS

individual teachers' perceived training needs taken into consideration in determining the training objectives or the contents specifically in fostering HOTS in science teaching. Since teachers are directly involved in the core education process that is, student learning, teachers involvement in planning process of the training is integral.

A deliberate intervention in the form of improved in-service teacher training is needed to raise Malaysian students' HOTS science-testing outcome and further reduce the gap with high achieving countries. Internationally, 43 percent of 15-year- old, failed to meet the OECD average in science in PISA 2009 (Malaysia Education Blueprint, 2013). According to Keeley, (2009) ensuring a strong foundation in science learning at lower secondary is imperative in meeting the demand of the future workforce (cited in Carver, 2012). Therefore, building the capacity for teachers to deliver highly effective science lessons at lower secondary level is important.

High competency in science content knowledge as well as HOTS is one of the determinant factors in Malaysia's journey to educational excellence. Teachers are held accountable and responsible in shaping students' competencies. A collaborative and constructivist learning environment which are conducive in fostering HOTS calls for assistance of facilitator or manager instead of instructors (Gabrscek \& Roeders, 2013). Transformation of the role of teachers demands for the updating, upskilling and upgrading to improve on the quality of the teachers. The need for preparation to foster HOTS in aspiring teachers is addressed by teacher education program in teacher training colleges and universities. However to prepare in-service teachers to meet the new demand, a provision for efficient, effective and relevant training program is necessary. In-service training is recognized as central to the development of quality of the inservice teachers (Gabrscek \& Roeders, 2013), as it is strongly related to change process (Roger, 1993). Harris (1980) asserts that, in-service training should take the shape as determined by its participant in order the most learning of the most suitable type takes place (Roger, 1993).

The latest 2015 PISA results show that Malaysia is still at the one-third bottom range among 76 participating countries worldwide despite an all-out effort by the ministry to train science teachers on how to teach students to think at the higher level several months before the test. Regular in-service training on student-centered pedagogy has also been provided by the ministry, but a study by AKEPT in 2011 shows that more than $50 \%$ of the teachers observed fail to deliver their lessons effectively, particularly in inculcating higher order thinking. To ensure a training programme delivers the desired results, it has to be designed based on an empirically tested framework of good design that takes into account all aspects of the training programme. Developing a training programme without a solid basis will almost always result in a waste of valuable resources.

Therefore, the main purpose of this research is to develop a framework for designing an effective in-service teacher training program with a focus on the training of how to teach thinking and investigate the impact of the training program at the individual level for secondary science in-service teachers in selected schools in Perak, Malaysia. The results of the study contribute to our understanding of the process of training transfer and effectiveness and the framework itself may also be useful for any Human Resource Development (HRD) in planning, implementing and 


\section{INTERNATIONAL JOURNAL OF ACADEMIC RESEARCH IN PROGRESSIVE EDUCATION AND}

DEVELOPMENT

Vol. 7, No. 3, July 2018, E-ISSN: 2226-6348 @ 2018 HRMARS

evaluating intervention programs that will bring about the desired outcomes at the individual and organisational level such as economic benefits, human good or to focus more specifically on return on investment. The development of the framework to design the training program can be referred to Nurulhuda et al. (2018). Specifically in this article, we will be only focusing on the impact of fostering HOTS training program on science teachers' knowledge. We would like to investigate whether the HOTS training given to the secondary science in-service teachers have a positive impact on their knowledge on fostering HOTS in the teaching and learning of Science.

\section{Literature Review}

\section{Malaysian Students' Performance in TIMSS and PISA}

One area of interest in education is comparative studies in educational achievement, in particular, in science, mathematics, and reading. There are two such international studies involving science, namely, Trends in International Mathematics and Science Study (TIMSS). and Programme for International Student Assessment (PISA). Each study of TIMSS or PISA involves approximately 50 countries and thousands of students in each participating country. The impact of both TIMSS and PISA paved a new direction for science and mathematics education in Malaysia (Sumintono, 2015, Nor'ain \& Chinnapan, 2016, Nor'ain, Marzita \& Mazlini, 2017).

Malaysia participated in TIMSS since 1999 and has been joining four cycles of assessment. The results showed the most drastic decline compared to other countries. Malaysian students' science achievement increased slightly between 1999 and 2003, but after that it declined in terms of rank and score, to below the international average in 2011. As for PISA, Malaysia had participated in the years 2009 and 2012, and the results obtained for science placed Malaysia's students in rank 53 among the 74 countries that participated. These results were below the international average. Further analysis from Ministry of Education (2013, p. 3-12) stated that for science, Malaysian students "have very limited scientific knowledge that can only be applied to a few familiar situations. They can present scientific explanation that follows explicitly from the given evidence but will struggle to draw conclusions or make interpretations from simple investigations." This was a wake-up call for the Malaysian government to do something with regards to improving the quality of science and mathematics teaching in the country. However, the results achieved for PISA 2015 showed that Malaysia has moving towards hitting the global average score of 493 for science. $60 \%$ of the students who participated grasped the basic knowledge and skills. The improved results of PISA 2015 may attributes to the implementation of HOTS since 2012.

The Malaysian Ministry of Education has taken drastic action to address this condition. Since improving the current science curriculum has been stated in the Education Blueprint (Ministry of Education, 2013), the revisions are targeted for completion in 2017 where one of the content of the new science curriculum will be to incorporate more problem-based and project-based subjects, formative assessments and an accelerated learning pathway for high performing students to complete their secondary education in four rather than five years.

Another emphasis recommended by the Education Blueprint is that Malaysian students have to cultivate HOTS. Again, the expectation is for students to be globally competitive and remain 
DEVELOPMENT

Vol. 7, No. 3, July 2018, E-ISSN: 2226-6348 @ 2018 HRMARS

relevant with the expectations of the industry and current market, and be able to face the increasing international challenges and competitions, benchmarked by international measurements, TIMSS and PISA.

Further, the Ministry of Education has taken strategic initiatives to set up a special task force in 2012 (Ministry of Education, 2013), for the purpose of enhancing HOTS among students and also for the continuous professional development of teachers. A well designed literacy programme is being developed to improve HOTS among students, as well as to provide teachers the teaching support needed for their 'diagnostic assessment' and for monitoring students' academic achievements. The task force consists of experts and university lecturers working together with RECSAM (The Regional Centre for Education in Science and Mathematics), where they discussed and designed a pattern of teaching for teachers to be more challenging to students by applying higher order thinking skills

Currently, Malaysia also participated in PISA 2015. The results achieved for PISA 2015 showed that Malaysia has moving towards hitting the global average score of 493 for science. $60 \%$ of the students who participated grasped the basic knowledge and skills. The improved results of PISA 2015 may attributes to the implementation of HOTS since 2012 as well as science offered in public examinations was upgraded by increasing its level of difficulty to make it fit in with HOTS (Sumitomo, 2015). Malaysian Ministry of Education aimed to achieve above the global average and be in the top one-third of countries participating in PISA and TIMSS by 2025, which is in line with the Malaysian Education Blueprint 2013-2025 (Ministry of Education, 2013).

\section{Training Evaluation and Effectiveness}

Training is a process which endeavours to impart knowledge, skills and attitudes necessary to perform job-related tasks. It aims to improve job performance in a direct way (Abella, 1990). Goldsmith (1993) defines training as a systematic approach to helping individuals to improve their performance. In general there is a need to train employees when new challenges in the work environment demand employees to keep up with the latest changes. Thus training is always a means to an end, not an end in itself. Unless the training improves the performance of work in an organisation, it inevitably incurs a waste of valuable resources (Goldsmith, 1993). This is the concept of training transfer and its sustainability. It is the application of learned knowledge, skills and attitudes to the job and subsequent maintenance over time for the purposes of improving the job performance (Cornelia \& Laura, 2016, Ng \& Rusli, 2018).

Defining training effectiveness is complex which has implications for the development of strategies to measure training effectiveness. The term "training evaluation" and "training effectiveness" had been distinguished by Alvarez, Salas and Garofano (2004). The former is described as a measurement technique to find out if training goals have been met. The latter is a theoretical approach used to investigate the individual, training and organisational variables that are likely to influence training outcomes.

Previous training "evaluation" studies have been criticised for the lack of information provided on the impact of the training intervention at both the individual (level three) and the 
Vol. 7, No. 3, July 2018, E-ISSN: 2226-6348 @ 2018 HRMARS

organisational levels (level four) (Cheng \& Ho 2001), for the failure to identify sub-categories of learning (Alliger et al. 1997) or, to measure the "horizontal" impact of training at individual level (Kearns 2005) such as the impact on the team or the unit. Wang and Sun (2009) suggest that the purpose of investing in employees is to enhance their current and future productivity for the organisation. For example, Mayo (2000) suggests that HRD can contribute to employee added value through increased motivation, commitment, efficiency and competence.

Evaluation of interventions (in this research it is training) is among the most critical issues faced by the field of Human Resource Development (HRD). There is an intense pressure for HRD to demonstrate that an intervention contribute directly to the organization's 'bottom line' (Holton, 1996). The dominant evaluation model, the four-level Kirkpatrick model (Kirkpatrick, 1976) is acknowledged by many practitioners as the standard in the field but is seldom fully implemented in organisations (Kimmerling, 1993). The four-level evaluation model consists of reactions, learning, behaviour and results. The reaction level measures how the trainees reacted to the training. Measuring reaction helps the organiser to understand how well the training was received by the audience. It also helps the organiser to improve the training for future trainees, including identifying important areas or topics that are missing from the training.

The learning level measures what the trainees have learned. It is important to measure this, because knowing what the trainees are learning and what they are not will help the organiser improve future training. The behaviour level evaluates how far the trainees have changed their behavior, based on the training they received. Specifically, this looks at how trainees apply the information (individual level). It is important to realise that behavior can only change if conditions are favorable. Hence there are many factors be it internal and/or external to the trainees that can affect behaviour change such as motivation, environmental and ability elements (Holton, 1996). Finally the results level analyses the final results of the training. This includes outcomes that the organisation have determined to be good for business, good for the employees, or good for the bottom line (organisational level). This article focuses only on the learning level in which the specific objective is to determine the impact of fostering higher order thinking skills training programme on science teachers' knowledge.

\section{Methodology \\ Method}

A one short experimental design was used to gather data in this research. A quantitative methods of inquiry were utilised which involved the use of an Inventory of Fostering HOTS in teaching and learning instrument. Finally, data was gathered from participants who took part in the research, where the pre-test and post-test were administered before and after the intervention.

\section{Training Intervention under Investigation}

The intervention utilised for the purposes of the study was a 36-hour and six-month Face-toFace Training Programme for Enhancing Teaching and Learning designed specifically to foster HOTS. The activity in the training programme provides course participants with the knowledge and skills to develop higher order thinking skills. Table 1 showed the specific programme component and curriculum structure in the training programmes. 
INTERNATIONAL JOURNAL OF ACADEMIC RESEARCH IN PROGRESSIVE EDUCATION AND

DEVELOPMENT

Vol. 7, No. 3, July 2018, E-ISSN: 2226-6348 @ 2018 HRMARS

Table 1

Programme Component and Curriculum Structure in the Training Programmes

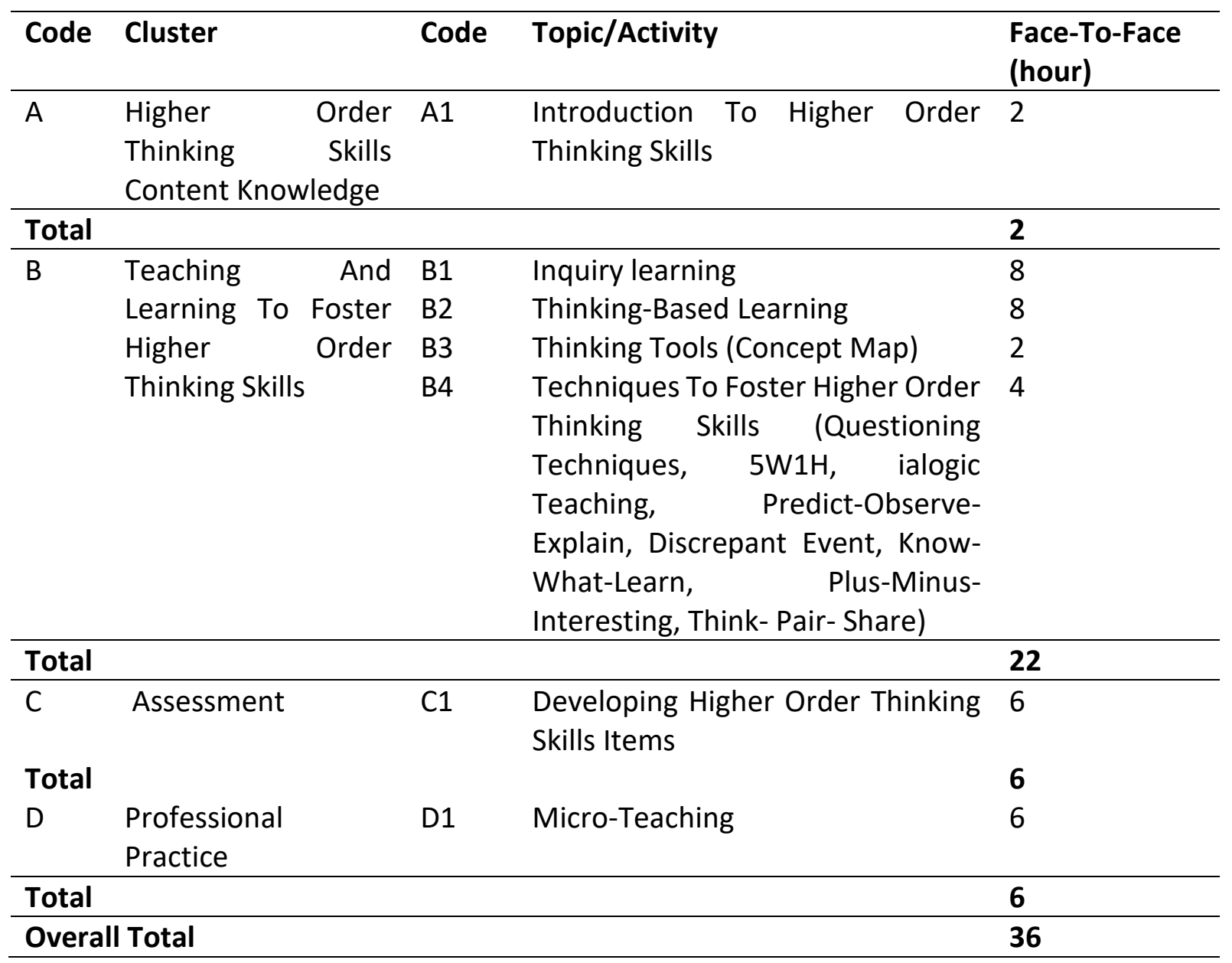

The training is divided into four clusters namely (A) Higher Order Thinking Skills Content Knowledge, (B) Teaching and Learning to Foster Higher Order Thinking Skills, (C) Assessment and (D) Professional Practice. Cluster A, C and D comprised of a topic or an activity such as Introduction to Higher Order Thinking Skills topic, Developing Higher Order Thinking Skills Items topic and Micro-Teaching activity, respectively. Cluster B comprised of four components; Inquiry learning; Thinking-Based Learning Thinking Tools (Concept Map); Techniques To Foster Higher Order Thinking Skills (Questioning Techniques, 5W1H, Dialogic Teaching, Predict-ObserveExplain, Discrepant Event, Know-What-Learn, Plus-Minus-Interesting, Think- Pair- Share).

\section{Sample and Procedure}

The sample used for this research was nine science teachers who completed the training intervention across seven topics or activities. They were selected using the purposive sampling technique which was according to the need of the research; teachers that are teaching science lower secondary school and were voluntary participants. At the early stage, there were 17 science 
Vol. 7, No. 3, July 2018, E-ISSN: 2226-6348 @ 2018 HRMARS

teachers recruited before the training, however only nine of them were fully completed all sessions in the training intervention.

\section{Instrument and Data Analysis}

The instrument used in this research is the Teaching and Learning in Fostering HOTS Understanding Inventory. It was designed to measure the science teachers' information and facts about HOTS and methods/activities/techniques to foster HOTS that a participant possesses. This instrument consisted of 13 multiple choice questions and six subjective questions that cover all topics and activities covered in the training intervention. The instrument was validated by education experts and had a high content validity index value of 0.96 . The index value of the Cronbach alpha was 0.78 , indicated that the instrument was suitable to be used in the research. Analysis of data was done using descriptive statistics, namely the mean and the standard deviation.

\section{Findings and Discussion}

Two sets of data were obtained immediately after intervention; the pre-test and post-test. Both data were to assess teachers' performance in the learning of information and facts about HOTS and methods/activities/techniques to foster HOTS. Teachers' performance was measured by the overall test performance in the Teaching and Learning in Fostering HOTS Understanding Inventory. Table 2 showed the results of the analysis. The overall total test performance was 40 marks, comprised of a total of 13 marks for multiple choice questions and 27 marks for subjective questions.

Table 2

Teachers' Performance in the Teaching and Learning in Fostering HOTS Understanding Inventory

\begin{tabular}{lllllll}
\hline Partipant & $\begin{array}{l}\text { Pre-Test } \\
\text { (Objectiv } \\
\text { e) }\end{array}$ & $\begin{array}{l}\text { Pre-Test } \\
\text { (Subjecti } \\
\text { ve) }\end{array}$ & $\begin{array}{l}\text { Total } \\
\text { Marks } \\
\text { (Pre-Test) }\end{array}$ & $\begin{array}{l}\text { Post-Test } \\
\text { (Objectiv } \\
\text { e) }\end{array}$ & $\begin{array}{l}\text { Post-Test } \\
\text { (Subjectiv } \\
\text { e) }\end{array}$ & $\begin{array}{l}\text { Total } \\
\text { Marks } \\
\text { (Post } \\
\text { test) }\end{array}$ \\
\hline 1 & 10 & 13 & $\mathbf{2 3}$ & 11 & 13 & $\mathbf{2 4}$ \\
2 & 7 & 13 & $\mathbf{2 0}$ & 9 & 13 & $\mathbf{2 2}$ \\
3 & 7 & 4 & $\mathbf{1 1}$ & 7 & 15 & $\mathbf{2 2}$ \\
4 & 6 & 12 & $\mathbf{1 8}$ & 7 & 10 & $\mathbf{1 7}$ \\
5 & 6 & 6 & $\mathbf{1 2}$ & 10 & 15 & $\mathbf{2 5}$ \\
6 & 8 & 3 & $\mathbf{1 1}$ & 9 & 15 & $\mathbf{2 4}$ \\
7 & 8 & 11 & $\mathbf{1 9}$ & 8 & 13 & $\mathbf{2 1}$ \\
8 & 9 & 11 & $\mathbf{2 0}$ & 9 & 11 & $\mathbf{2 0}$ \\
9 & 7 & 10 & $\mathbf{1 7}$ & 8 & 16 & $\mathbf{2 4}$ \\
\hline Mean & $\mathbf{7 . 5 6}$ & $\mathbf{9 . 2 0}$ & $\mathbf{1 6 . 7 8}$ & $\mathbf{8 . 6 7}$ & $\mathbf{1 5 . 1 1}$ & $\mathbf{2 2 . 1 1}$ \\
\hline
\end{tabular}

The overall mean performance for the pre-test and post-test were 16.78 and 22.11, respectively. Specifically, for the multiple choice questions, the mean for the pre-test was 7.56, while the post-test was 8.67. Furthermore, for the subjective questions, the mean for the pre- 
Vol. 7, No. 3, July 2018, E-ISSN: 2226-6348 @ 2018 HRMARS

test was 9.20, while the post-test was 15.11. The results showed that the teachers' performance was better after the intervention; their score increased by 5.33 points in overall mean performance, 5.91 points in the subjective questions, and 1.11 point in the multiple choice questions.

Looking closely into each question in the instrument, it was noted that, a subjective question related to thinking-based learning had been answered well by almost of the participants in the post-test. Barak and Shakhman (2008) emphasised that introducing elements of constructivist pedagogy combined with specific steps aimed at fostering higher-order thinking into class could be a realistic aim for teachers. One example of a systematic approach of fostering thinking in teaching a specific content is the IERT model (Swartz \& McGuinness, 2014), namely the thinkingbased learning that was done in the training intervention in this research.

Based on Table 2, it is found that participant 4 had less marks for subjective questions in the post-test as compared to the pre-test. The participant's score had decreased by 2 points. By examining and comparing both pre-test and post-test, it was noted that the participant had missed one subjective question related to giving examples of HOTS in the post-test. This might be due to carelessness. However, working carelessly and making errors do not reflect ones knowledge (Hershkovitz et al. 2011). In addition, participant 8 had equal score for subjective questions in both post-test and pre-test. By comparing both tests revealed that this participant too had missed the same subjective question that was missed by participant 4 which was related to giving examples of HOTS in the post-test.

With regards to measuring the impact of the training intervention, the primary concern relates more to demonstrating a link between the training intervention and the results observed, especially in the case of science teachers' information and facts about HOTS and methods/activities/techniques to foster HOTS which, according to Spitzer (2005), Hamtini (2008), Rüth \& Kaspar (2017) most evaluation models fail to accommodate. Results demonstrated an improvement of participants' understanding of information and facts about HOTS and methods/activities/techniques to foster HOTS. This study confirmed the recommendations suggested by Saedah and Omed (2015) and Gullistin et al. (2017), such that HOT skills acquisition can also be enhanced through science teacher in-service professional development programs on how to use the curriculum to impart understanding of scientific concepts and their applications in daily life. Another study by Weinberger and Zohar (2000) in preparing prospective teachers to integrate instruction of higher order thinking skills into science topics found that there was a developmental positive trend in several different aspects, on both a cognitive and an affective level which aligned with this research. In addition, this study also support Balakrishnan et al. (2016) recommendation's that a well-designed and planned approach which are related to specific learning content that are challenging would promote higher order thinking skills. These are core principles of good teaching and have a powerful relationship.

\section{Conclusion and Implications}

This study adopted a one shot experimental design to measure the impact of a face-to-face training intervention on teaching and learning in fostering HOTS to lower secondary school 
Vol. 7, No. 3, July 2018, E-ISSN: 2226-6348 @ 2018 HRMARS

science teachers. The result revealed that there is a positive impact on science teachers' knowledge based on the performance score achieved in the Teaching and Learning in Fostering HOTS Understanding Inventory. The HOTS training that was design based on the developed framework showed a significant impact on science teachers' knowledge; the participating science teachers were competent in implementing active learning methods with a focus on teaching thinking. In addition, competent science teachers who participated in the research would impact on their students' capability to think and in the long run produce citizen who are thinkers, not only as consumers of knowledge but also producers of knowledge, hence improved the TIMSS and PISA results for Malaysia.

\section{Acknowledgement}

We extend our gratitude to the Ministry of Education, Malaysia for providing the funds under the Fundamental Research Grant Scheme (FRGS): 2015-0169-107-02 and Sultan Idris Education University for providing the official approval that enabled us to conduct the research. Special thanks to the science teachers from the secondary schools in Malaysia for their involvement in this research.

\section{Corresponding Author:}

Associate Prof. Dr Nor'ain Mohd Tajudin

Mathematics Department, Faculty of Science and Mathematics, Sultan Idris Education University, 35900 Tanjong Malim, Perak, MALAYSIA

Email: norain@fsmt.upsi.edu.my

\section{References}

Abella, K. T. (1990). Building Successful Training Programs (5th Ed.). Massachusetts: AddisonWesley Publishing Company, Inc.

Alliger, G. M., Tannenbaum, S. I., Bennett, W., Jr., Traver, H., \& Shotland, A. (1997). A metaanalysis of relations among training criteria. Personnel Psychology, 50, 341-358. (15) Effectiveness of Training in Organizations: A Meta-Analysis of Design and Evaluation Features.

https://www.researchgate.net/publication/10773180_Effectiveness_of_Training_in_Organizati ons_A_Meta-Analysis_of_Design_and_Evaluation_Features

Alvarez, K., Sales, E., \& Garofano. (2004).An integrated model of training evaluation and effectiveness. Human Resources Development Review, 3(4), 385-416.

https://doi.org/10.1177/1534484304270820

Barak, M. \& Shakhman, L. (2008) Fostering higher-order thinking in science class: teachers' reflections, Teachers and Teaching, 14:3, 191-208, DOI: 10.1080/13540600802006079 
INTERNATIONAL JOURNAL OF ACADEMIC RESEARCH IN PROGRESSIVE EDUCATION AND

DEVELOPMENT

Vol. 7, No. 3, July 2018, E-ISSN: 2226-6348 @ 2018 HRMARS

Bobko, P. \& Russell, C. (1991). A review of the role of taxanomies in human resources management. Human Resource Management Review, 4, 293-316.

Burke, L. A. \& Hutchins, H. M. (2008). A study of best practices in training transfer and proposed model of transfer. Human Resource Development Quarterly, 19 (2), pp. 107-128.

Cornelia, T. \& Laura, B. (2016). Determinants of transfer of training: A comprehensive literature review International journal for research in vocational education and training, 3 (2), 127-165.

Cheng, E. W. L. \& Ho, D.C. K. (2001). A review of transfer of training studies in the past decade. Personnel Review, 30 (1), 102-118.

Goldsmith, I. L. (1993). Training in Organisations (3rd Ed.). Pacific Grove: Brooks Cole.

Hamtini, T. M. (2008). Evaluating E-learning Programs: An Adaptation of Kirkpatrick's Model to Accommodate E-learning Environments. Journal of Computer Science, 4 (8), 693-698.

https://www.researchgate.net/publication/26622055_Evaluating_E-

learning_Programs_An_Adaptation_of_Kirkpatrick\%27s_Model_to_Accommodate_Elearning_Environments

Hershkovitz, A., Wixon, M., Baker, R. S. J. d., Gobert, J., \& Sao Pedro, M. (2011). Carelessness and goal orientation in a science microworld. In J. Kay, S. Bull, \& G. Biswas (Eds.), Proceedings of the 15th International Conference on Artificial Intelligence in Education (pp. 462-465). Berlin: Springer.

Holton, E. F. (1996). The flawed four-level evaluation model. Human Resource Quarterly, 7 (1).521.

Holton, E. F., Chen, Hsin-Chih, \& Naquin, S. S. (2003). An examination of learning transfer system characteristics across organisational settings. Human Resources Development Quarterly, 14 (4), 459.

Hutchins, H. M. and Burke, L. A. 2007. Identifying trainers' knowledge of training transfer research findings - closing the gap between research and practice. International Journal of Training and Development, 11 (4), 236-264.

Kearns, P. 2005. From return on investment to added value evaluation: the foundation for organisational learning. Advances in Developing Human Resources, 7 (1), 135-146.

Kimmerling, G. (1993). Gathering the best practices. Training and Development, 47, 29-36.

Kirkpatrick, D. L. (1976). Evaluation of training. In R. L. Craig (Ed.), Training and Development Handbook. New York: McGraw-Hill. 
INTERNATIONAL JOURNAL OF ACADEMIC RESEARCH IN PROGRESSIVE EDUCATION AND DEVELOPMENT

Vol. 7, No. 3, July 2018, E-ISSN: 2226-6348 @ 2018 HRMARS

Ng, K. H. \& Rusli, A. (2018). Personality traits, social support, and training transfer, Personnel Review, 47 (1), 39.

Martin, H. J. (2010). Workplace climate and peer support as determinants of training transfer. Human Resource Development Quarterly , 21 (1),87-104.

Mayo, A. (2000). The role of employee development in the growth of intellectual capital. Personnel Review, 29 (4), 521-533.

Ministry of Education. (2013). Pelan PembanguNan Pendidikan Malaysia 2013-2025. Putrajaya, Malaysia: Kementerian Pendidikan Malaysia.

Ruona, W.E.A., Leimbach, M, Holton, E.F. and Bates, R. A. (2002). The relationship between learner utility reactions and predicted learning transfer among trainee. International Journal of Training and Development, 6 (4), 218-228.

Gulistan, M. S., Saedah, S.. Abu Bakar, N., Al Amedy, Omed, S. (2017). Teaching Strategies for Promoting Higher Order Thinking Skills: A Case oOf Secondary Science Teachers. MOJEM: Malaysian Online Journal of Educational Management, 3(4), 16-30. http://Mojem.Um.Edu.My/Index.Php/MOJEM/Article/View/6077.

Rüth, M. \& Kaspar, K, (2017). The E-Learning Setting Circle: First Steps Toward Theory Development in ELearning Research, The Electronic Journal of e-Learning, 15(1), 94-104.

Spitzer, D. R. (2005). Learning effectiveness measurement: a new approach for measuring and managing learning to achieve business results. Advances in Developing Human Resources, 7 (1), 55-71.

Sumintono, B. (2015). Science education in Malaysia: Challenges in the 21stcentury. In: 1st International Seminar on Science Education (ISSE) 2015, 31 October 2015 , Universitas Negeri Yogyakarta, Yogyakarta, Indonesia..

Swartz, R. \& McGuinness, C. (2014). Developing and Assessing Thinking Skills Project Final Report Part 1 February 2014 https://www.ibo.org/globalassets/.../ib.../student-thinking-skills-reportpart-1.pdf

Van der Klink, M. R., Gielen, E. E. M., \& Nauta, C. (2001). Supervisory support as a major condition to enhance transfer. International Journal of Training and Development, 5 (1), 52-63.

Wang, G. \& Sun, J. Y. (2009). Perspectives on theory. Clarifying the boundaries of human resource development. Human Resource Development International, 2 (1), 93-102.

Weinberger, Y., Zohar, A. (2000). Higher Order Thinking in Science Teacher Education in Israel. In Abell S.K. (eds), Science Teacher Education. Science \& Technology Education Library, vol 10. Springer, Dordrecht. 